\title{
Biologising Paternity, Moralising Maternity: The Construction of Parenthood in the Determination of Paternity Through the Courts in Portugal
}

\author{
Helena Machado
}

Published online: 1 August 2008

(C) Springer Science+Business Media B.V. 2008

\begin{abstract}
This article explores how the Portuguese legal system's efforts to determine paternity of children born outside legal marriage, automatically initiated by the Registry Office when a birth registration does not indicate the father, reveal cultural models which reinforce the naturalisation of the differences between mothers and fathers, with significant effects on the social construction of parental roles and on expectations of family organisation and female sexual behaviour. The article relies on ethnographic data drawn from direct observation of court proceedings for the determination of paternity, as well as interviews with judges and prosecuting counsels all over the country. It is argued that judicial practices in the specific context of courtroom investigations of paternity reinforce gender inequalities in two interrelated ways. On the one hand, they are strengthened in the discursive practices performed during the course of the interactions between judges, prosecuting counsels and the mother of the child, as well as the alleged father. On the other hand, the normative model of family life and the dominant ideology of women's and men's relationships, which emphasise women's socially subordinate position, are revealed by the selective use of DNA testing in paternity cases, based on the judge's evaluation of the mother's sexual behaviour. The article argues that legal attempts to establish the paternity of children born outside marriage-though based on novel technical and supposedly objective procedures-tend, nevertheless, to reproduce the prevailing patriarchal structures.
\end{abstract}

Keywords Children's rights · Court proceedings · Family ideologies · Family law · Gender inequality · Legal discourse · Parenthood · Paternity testing · Sexual norms · Unmarried mothers

H. Machado $(\bowtie)$

Department of Sociology, Research Centre for the Social Sciences, University of Minho, 4710-057 Braga, Portugal

e-mail: hmachado@ics.uminho.pt 


\section{Introduction}

Children born outside institutional marriage without a legal father, together with the uncertainty of biological paternity, have always posed a problem for legal systems that based ownership and inheritance of property on descent through the male line. Carol Smart puts it in these terms: "[Historically], paternity has been a continuing 'problem' for the patriarchal family in Western Europe... and this is manifest in the tortuous, complex nature of the legal system designed to protect the descent of property and privilege" (Smart 1987, p. 99).

It has not always been usual to establish the link between a child and his or her parents when the child is born to an unmarried woman. Ancient societies commonly denied family ties between such a child and his or her father. In ancient Roman law, a child born out of marriage was a filius nullius, that is, he or she had no family ties with any of his or her parents (not even with his or her mother). It has not been self-evident that such a child should be entitled to financial support from his or her father, or that he or she should have the right to inherit from him (or his relatives). In fact, until the 1970s, affiliation laws in most western European countries protected the 'legitimate family'. There were very limited conditions for admissibility of a paternity investigation and it was almost impossible to recognise paternity in the case of a married man: the law almost appeared to have been designed to give the putative father a "sporting chance to get away with it" (Barton and Douglas 1995, p. 200).

Despite some differences in family law systems concerning affiliation laws, most Western European legal systems are historically interconnected and have common legal provisions, such as the application of the Roman law rule of the presumption of paternity-Pater est quem nuptiae demonstrate-which ties men legally to any children born to their wives (Assier-Andrieu and Commaille 1995; Boele-Woelki 2003; Council of Europe 1999; Diduck and Kaganas 1999; Eekelaar and Sarcevic 1993; European Commission 1997; Forder 1993; McGlynn 2006). Even if there is no biological tie between the child and the mother's husband, the law considers that the husband is the legal father and in most countries it is necessary to take civil proceeding in order to remove that presumption of paternity. As such, marriage retains a privileged place as the preferred way of attributing paternity (Sheldon 2005 , p. 541). In relation to children born outside legal marriage, however, the problem of paternity remains. If the unmarried father voluntarily registers the child's birth with the mother, he will automatically be recognised as the legal father. But when that does not occur and the birth certificate does not indicate the identity of the child's father, efforts may be made to establish fatherhood via court proceedings. In Portugal, since the Civil Code of 1966, it is the state's obligation to

\footnotetext{
1 In France, the Civil Code of 1804 forbade trying to establish the identity of the father of a child born to an unmarried woman. In Portugal, the Civil Code of 1867 imposed several restrictions on the investigation of paternity in order to protect the legitimate family. By contrast, in ancient Nordic law, the link between a child born to an unmarried woman and its father was acknowledged, and it seems to be characteristic of the Nordic countries that the task of establishing paternity of non-marital children (in Sweden since the late 1910s) should fall on society. The legal situation in the Nordic countries is not, however, identical in all aspects, for example on the question of how a refusal on the part of the mother to co-operate in the identification of the father is regarded (Eekelaar and Sarcevic 1993).
} 
initiate paternity establishment proceedings when no father is listed on the birth registration. This obligation ends when the child reaches the age of 2 , and after that period a determination of paternity can only be sought by the mother, the putative father or the child after coming of age. This article will focus on cases in which paternity establishment is automatically initiated by the Registry Office when no father is listed on a child's birth registration.

Although provisions concerning the investigation of paternity of children born outside marriage may vary between national legal systems, ${ }^{2}$ almost all European societies now support efforts to establish parentage in these cases. During the last decades, the European integration of family law paradigms has become ever more apparent, as "the new Europe is very much a legalistic Europe" (McGlynn 2006, p. 1). The potential impact on the rights of children proceeding from the European Convention on Human Rights and Fundamental Freedoms (ECHR) is of major importance. Some authors have pointed out that the ECHR is not a human rights document which is child-friendly (Kilkely 2000; McGlynn 2002). But it has been interpreted to include some rights for children and as protecting their interests in some circumstances. Article 8 (the right to respect for family and private life), for example, has been held to include the right to establish facts about personal identity, including paternity (McGlynn 2002, 2006).

The degree of state efforts to establish paternity varies from country to country. The reasons for establishing parentage and the legal rules for doing so are the subject of debate and not self-evident. Most European societies support efforts to establish parenthood in order to promote the creation of families and to ensure that children are cared for not only financially but also with regards to education, upbringing and day-to-day care. There are also medical reasons to establish parentage, the main ones being to enable the child to know his or her personal medical history, and the importance of parents in the psychological development of infants. These reasons must not be underestimated. However, they do not mean that establishing parentage is necessarily important. It may not matter to the child if the male and female adults of his or her family are his or her legal parents or not. It may be claimed that the important thing is that there is someone who acts as a father and a mother towards the child (Eriksson and Saldeen 1993). At the other end of the spectrum, however, there is the possibility that the parent with custody (generally the mother) does not want the recognition or determination of paternity, because the child was born as a result of a transient or coercive relationship. The present UK law on parental responsibility, for example, protects women who are 'victims' of such circumstances by allowing the mother, in effect, to veto parental responsibility for an unmarried father, unless he can persuade a court to override her objections; although recent changes to UK law by way of the Child Support (Pensions and Social Security) Act 2000 allow courts to authorise blood testing of a child when the

\footnotetext{
${ }^{2}$ Several European countries, such as Scandinavian countries, Germany and Portugal have compulsory inquiries of paternity when the birth certificate of a child under 2 years old does not show the identity of the father. Other countries simply give the court the power to investigate paternity in the course of other civil proceedings regarding the child. That is the case in the UK, where family law allows the Secretary of State, the alleged father or the person with residence to apply for a declaration of parentage of the child (Cretney 2003).
} 
parent with custody refuses consent, but the court considers it to be in the child's best interest (Wallbank 2004).

Nevertheless, family law in most European countries over the last four decades has registered a shift towards the end of the disparity between children born in and out of wedlock, as well as an increased emphasis on children's right to have a mother and a father. The reasons for this general consensus are connected with personal, psychological, social, economic, moral and medical factors, which interrelate in complex ways. Particular controversies have arisen in relation to the invocation of the need to establish the paternity of children without a legal father, or whose legal father is not their biological father in the case of children born by assisted reproduction using donor sperm (Gilbar 2005). ${ }^{3}$ DNA testing can now reliably establish paternity, which raises ethical questions about the appropriate use of DNA-based paternity testing and social and policy questions about the role of biological links in grounding parental obligations and rights (Rothstein et al. 2005).

Some authors point out that the recent trends of affiliation laws in Europe have three common elements: equalisation, liberalisation and modernisation (Senaeve 1993). Regarding 'equalisation', the primary object and result of the reforms has been the elimination of discrimination between various categories of children (legitimate and illegitimate) on the grounds of birth. ${ }^{4}$ The liberalisation of affiliation laws has occurred in the sense of suppressing numerous restrictions on the establishment and contestation of affiliation. Finally, one of the most perceptible objectives of all these reforms has been to modernise affiliation laws by adapting them to new medico-genetic techniques, which allow a child to be conceived without sexual intercourse. Furthermore, attention has been given to the application of scientific proof of parentage, with a view to the establishment and contestation of maternity and paternity. Today, DNA profiling is indeed becoming increasingly important as part of the courts' procedures to investigate paternity of children born outside legal marriage, as well as when a voluntary recognition of paternity is not spontaneously made by the alleged father.

These profound modifications in family law reflect a set of conditions that arose in many countries, namely the considerable advances seen during the 1970 s in the field of genetics and particularly in the realm of investigation of biological paternity. Accompanying these scientific advances were certain ideological changes, evident in a greater concern to defend the rights of children born outside institutional

\footnotetext{
${ }^{3}$ In recent years there has been an intense public debate concerning the child's right to know its genetic origins. In the context of donor anonymity, the debate refers to the balance between the child's right to know (the ethics of 'rights', according to which priority is given to the right over the good) and the possible integrity of the family (the ethics of 'utility' by which the concern would be to balance the interests of all the parties, bearing in mind the consequences for individuals and for the family as a unit) (Wallbank 2004, p. 247).

${ }^{4}$ In the past four decades, all western European countries have carried out more or less substantial reforms of their affiliation laws to provide equality in all fields between children born within and outside of wedlock, with the elimination of the traditional institution of legitimacy and its accompanying terminology. Some outstanding examples of reforms of affiliation laws took place in the Netherlands (1969), France (1972), Switzerland (1976), Portugal (1977), Luxembourg (1979) and Belgium (1987). For further details on reforms of affiliation laws in Europe, see Senaeve (1993), Assier-Andrieu and Commaille (1995) and Spaas (1998).
} 
marriage, as well as in increasing state intervention to protect children and control parental authority (Meulders 1993). ${ }^{5}$ It was in this context that I undertook a study to investigate Portuguese court procedures for the determination of paternity out of wedlock, when the alleged father does not voluntarily recognise paternity.

The critical and theoretical approach of this study is based on two distinctive but congruent fields of scholarship. It endorses the currents of thought followed by cultural anthropology since Lévi-Strauss (1969), who argued that the reproduction of human beings is also the reproduction of social relationships (Smart 1987; Smart and Neale 1999; Spaas 1998; Strathern 1992); and it is also rooted in a tradition of feminist legal studies. The research explores the social relationships reproduced by the courts of law and evoked in the context of paternity investigations (i.e. in representations of paternity, maternity and family), which highlight the ideologically dominant gender relations and prevailing notions of parenthood, and reinforce the socially subordinate position of women.

The methodology of the study included direct observation of court proceedings in paternity cases in one court of law in the north of Portugal, selected to develop a case study, as well as interviews with judges and prosecuting counsels all over the country. This article will analyse two aspects of court procedures in paternity investigations. Firstly, based on feminist legal literature, I will consider the modes of domination of women by means of courtroom discourse (Cameron 1990; Conley and O'Barr 1998; Matoesian 1993). In particular, the discursive practices performed during the interrogations of the mother and the alleged father in the course of paternity investigations will be examined. Secondly, the selective uses of DNA testing in paternity cases, mainly based on the evaluation of the moral character of the child's mother, will be analysed. DNA testing — one of the technologies believed to be almost infallible - is ordered by the judge and is used in a restrictive and selective way, with the unrevealed objective of adapting individual demeanour to the standards of values and behaviour of the dominant social groups. This analysis will show that scientific knowledge both embeds and is embedded in social identities, institutions, representations and discourses (Jasanoff 2004) and that the uses of science in this context have an important impact, both ideological and in the normalisation of behaviour, namely when it comes to reproducing the prevailing patriarchal structures, in particular the privileging of biological kin relationships, the symbolic importance of the father and the imposition of feminine monogamy.

My main argument is that while the genetic expert reports reinforce a notion of paternity associated with biological determinism, the secure ascertaining of paternity gives the courts further power of control over those sexual and procreative female behaviours which break from the conventional standards of a woman's fidelity to a sole sexual partner. Thus, maternity is 'moralised'.

In the words of Gillian Douglas, the legal regulation of reproduction mainly reproduces patriarchal structures in society. As she points out:

\footnotetext{
5 The European concern over the rights of children born outside marriage is evident in the European Convention on the Judicial Status of Children Born Outside of Wedlock (15 October 1975), which specified the need for the member states of the European Council to adopt common judicial dispositions on this matter.
} 
On a more basic level, while women have almost total power over reproduction, because they bear the child, they have been unable to make use of this power. No man can be certain if a child is his, short of having genetic testing to find out. Nonetheless, all women, until the past decade, have known that the child they carry is 'theirs'. Patriarchal structures in society might be said to be based on the desire of men to seek to control this power that women have, to try to ensure that a child belongs to the right man. (Douglas 1991, p. xix)

This seems to be emphasised by the phenomenon of children born outside legal marriage and who have no legal father, combined with the uncertainty of biological paternity, and often reinforced by assumptions about women's predilection for deception in reproductive matters (Diduck and Kaganas 1999, p. 130).

Feminist legal studies have shown that lawsuits that evoke sexuality-such as those relating to rape, sexual assault, abortion, assisted reproduction techniques, and I now add to this list judicial investigations for the determination of paternityhighlight mechanisms by which the law ascribes specific meanings to women's bodies and behaviours (Abbott and Wallace 1991; Bridgeman and Millns 1995; Gruen and Panichas 1997; Mackinnon 1987; Matoesian 1993; Pineau 1997; Smart 1995). In this process they reproduce cultural beliefs about female sexuality and show how the law has its own very powerful mode of disqualification and subordination of women. This article follows the feminist legal studies agenda in the way Richardson (2005) suggests: "Instead of creating the identity of the womanvictim, feminism has questioned the meaning of what it is to be a woman. This has allowed feminism to challenge rather than create such a victim identity" (Richardson 2005, p. 291).

\section{Paternity Investigation Proceedings in Portugal}

One hundred years after the creation of the first Portuguese Civil Code in 1867, a new Civil Code was produced in 1966, which consolidated the binding of the code's social ethics to a Catholic morality, thus reinforcing the dictatorial regime's doctrinal project, begun in 1926 and coming to an end with the so-called 'April Revolution' in 1974. The change in the legislation created an obligation on the state to assume the role of petitioner in paternity investigations, whenever a birth certificate was found which did not identify the child's father (article 1860). However, legal recognition of paternity was to be performed in such a way as to "protect the legitimate family or the dignity and honor of unmarried individuals" (Pinto 1995, p. 271).

Since the family law changes were introduced in Portugal in 1966, the legal system provides for an "unofficial inquiry of paternity", which occurs in a court of law and investigates the paternity of any minor under the age of 2 whose birth record does not show the identity of the father. ${ }^{6}$ The law requires the clerk at the

\footnotetext{
6 Article 1864 of the Civil Code states: "At any time that a minor's birth register is made in which only the maternity is established, the clerk is bound to forward an unabridged register certificate to the court so that the father's identity may be unofficially investigated".
} 
Registry Office to forward to the proper court a copy of any birth certificate that only indicates the mother's identity, with the exception of cases in which the clerk can verify that the registered minor was born of an incestuous relationship. ${ }^{7}$

The state's obligation to initiate a paternity investigation has been justified within the dominant juridical doctrine as necessary in order to protect the essential rights of the child whose paternity is not legally determined, such as the rights to "personal identity" and "the development of personality", 8 generally seen as associated with the "right to paternity" (Pinto 1995, 2004). The identity of an individual is thus reconfigured according to biological affiliation, a form of symbolical domination which has resulted in the emergence of new rights, such as the "right to genetic information" (Eriksson and Saldeen 1993; Wallbank 2004). One of the judges interviewed clearly stated the privileging of biological paternity by the Portuguese judicial system: "There are no human rights that rise above the determination of paternity, there aren't. That determination comes with a natural force, supernatural!" 9

The duty to protect and defend the best interest of children born outside matrimony is assumed by the Portuguese state by enforcing procedures that aim to equalise those cases with the situation of families considered 'normal', with the purpose of ensuring legal parity between children born within and outside legal wedlock. The dominant concept of family in western legal frameworks is characterised not only by the privileging of biological affiliation (Strathern 1992), but also by the image of the breadwinner male and its corresponding configuration of paternity as financial and moral support of the family (Eaton 1986). Although the legal conception of parental duties appeals to the obligation of both mothers and fathers to ensure the child's well-being, namely through economic resources and emotional support, the maternal role is more or less explicitly played under the yoke of emotional and financial dependence on the father. As Pat Carlen and Anne Worral emphasise in their analysis of the ways in which the judicial system deals with women, one of the pillars of the juridical construction of femininity is a normative definition of 'motherhood' which evokes the conceptions of frailty and weakness: "The 'normal' mother is both economically and emotionally dependent on the father of her child, and it is considered essential to the child's welfare to have two parents in situ in the family home" (Carlen and Worral 1987, p. 3).

The examining stage of paternity investigation proceedings is conducted under the jurisdiction of the prosecuting counsel, who is required to gather all evidence deemed necessary for a reliable identification of the biological father of a given child. This may include holding an interview with the mother of the child whose

\footnotetext{
7 According to article 121, no 3 of the Registry Office Code, "the consignment of the certificate shall not take place if, knowing the name of the alleged father, the clerk verifies that he and the mother are blood relations or relatives by marriage".

8 Article 26, no 1 of the present Constitutional Law states that: "everyone has the right to personal identity, to the development of personality, to civil capacity, to citizenship, to good name and reputation, image, speech, respect for private and family life and to protection against all forms of discrimination". Children's rights to personal identity and development of personality are considered to justify the limitation or restriction of the supposed father's right of respect for private life and physical integrity. Hence, if the putative father refuses to submit to a paternity test, he may be taken to the place where the test is administered under police escort.

9 Interview with judge, 2001.
} 
paternity is being judicially investigated, interrogating the alleged father and witnesses, as well as requesting reports on the "moral and socio-economic situation" of the child's mother, which are generally performed by the National Guard (GNR), police force (PSP) or Social Services technicians from the Social Rehabilitation Institute. ${ }^{10}$ In more recent years, reports of genetic paternity tests have been incorporated as evidence in judicial investigations of paternity. The admission of scientific tests as evidence in paternity investigation proceedings was introduced in Portugal with the decree-law no 496/77 of 25 November, and sanctioned in article 1801 of the Civil Code, which states: "In lawsuits concerning affiliation, blood tests and any other scientifically reliable methods shall be admitted as evidence." However, until the 1990s, scientific tests were scarcely used in paternity cases in Portugal. In countries such as the USA or the UK, the use of DNA paternity testing in courts became common in the late 1980s (Derksen 2000), but in Portugal, courts have become more receptive to the use of genetic evidence only since the mid-1990s.

As soon as the evidence is gathered, a formal opinion is issued by the prosecuting counsel on the viability of an unofficial inquiry of paternity, so that an "ordinary lawsuit of paternity" can be pursued. ${ }^{11}$ This opinion may or may not be confirmed by a judge's ruling. If a judicial magistrate considers an unofficial inquiry of paternity viable, an ordinary lawsuit of paternity is initiated, in which the evidence gathered in the previous stage is presented once again, and other elements are eventually included. From this comes a new formal opinion laid down by a magistrate for the prosecuting counsel, who rules on its grounds (that is, the alleged father's paternity of the child) or groundlessness. The person indicated as being the father can, at any time during the judicial investigation of paternity, voluntarily acknowledge paternity of the child, in which case an affiliation certificate will be immediately drafted and the case closed.

Although the penetration of DNA profiling in the Portuguese courts seems to be significant, the most recent official statistics on the Portuguese justice system, covering the period 1996-2004, show that in $28 \%$ of cases the courts did not reach a determination of legal paternity, and in $56 \%$ of cases the legal determination of paternity was made because the alleged father voluntarily recognised paternity in the course of the investigation. This leaves only $16 \%$ of viable cases, that is, cases in which the evidence gathered was actually evaluated in open court. (Portuguese Ministry of Justice 1996-2004). This relatively low percentage of paternity cases that reached the court sessions can be explained by the selective use of genetic testing, based on the judge's evaluation of the mother's sexual and moral behaviour, as will be discussed below. I will argue that legal efforts to establish paternity depend on the production of evidence which, in this specific case, is mainly based

\footnotetext{
${ }^{10}$ This is a department of the Ministry of Justice which is responsible for, among other services, advisory reports regarding family law and juvenile penal matters, social or psychological analyses of ex-prisoners, drug addicts and juvenile delinquents in order to combat social exclusion, and the articulation between the administration of justice and the community.

11 Article 204, no 1 of the Minors Tutelary Organisation (Epifânio and Farinha 1992) states: “1. the judge will issue a final ruling as to whether to close the case or have it proceed to the magistrate for the prosecuting counsel of the proper court, so that an investigation or impugnment are recommended."
} 
on the evaluation of the mother's sexual and moral behaviour. Although the defence of the child's rights is the main goal of the courts' attempts to establish paternity, the selective and restrictive ways in which scientific evidence is used means that in practice, only children with 'well-behaved' mothers will have access to DNA paternity testing ordered by the court, and therefore, access to the legal determination of paternity. 'Well-behaved' women will be granted the benefit of paternity acknowledgement, which performs mainly the symbolic function of limiting the possible impacts of the social stigma that arises from the situation of having a child with an unknown father, whilst reinforcing the idea that the desire and purpose of every normal woman is to become a mother. Paternity acknowledgement works as a form of approach to a standard of family life considered to be acceptable, that is, the dominant ideology of family founded upon heterosexual marriage, the sexual division of labour and the moralisation of maternity. This implies, as one of its most visible effects, the recreation and reproduction of gendered social relations by which women are socially controlled in a subordinate and sexualised manner.

\section{Discursive Practices and Gendered Perceptions of Parenthood}

Discursive practices in the courtroom may reflect pre-existing gender differences and hierarchies of knowledge and power in society. My aim was to understand how this happens in the particular field of "legal language" 12 used in investigation of paternity hearings, in interrogations of the child's mother and the presumed father.

In the 1960s and 1970s, studies of judicial behaviour within trial courts focused on the recorded outcomes of legal procedures, specifically on sentencing behaviour. This meant that studies of judicial practices discovered in written records could be undertaken without ever setting foot in a trial court (Phillips 1998). At the same time, many sociolinguistic works on courtroom language have provided evidence that the ideology produced in judicial practices is constitutive of certain social processes, or incites certain social consequences (Jasanoff 2004; Smart 1987), and is related to everyday ideologies expressed in the family, in schools, in the media, and in the workplace (Eaton 1986; Phillips 1998), which suggests that the boundaries between law and non-law are permeable.

One of the aims of my study was to contribute to an understanding of how speakers create realities through the language used in courtrooms (Jasanoff 1998), in the specific context of judicial investigations of paternity. To achieve this goal, I spent 6 months in a court of law, between 1996 and 1997, attending the hearings conducted by a group of judges and prosecuting counsels, with whom I worked closely. I returned in 2000 and carried out fieldwork for a further 12 months. I have focused on the language used in court and on the model of specific gender roles, as

\footnotetext{
12 "Legal language" is here understood as all written and non-written statements produced by the different social actors within the context of the courtroom. I share Conklin's (1998) opinion that the distinction between the concepts of 'language' and 'discourse' are of little analytical importance, in that they are very closely linked and both have to do with ways of expressing 'power' (Conklin 1998, p. 8), so in the following discussion I will use both terms without distinction.
} 
well as the constructions of feminine sexuality observed in those interactions. This approach is rooted within a feminist tradition of legal studies. The research aimed to understand how the language used in court reproduces the social construction of gender roles, and of 'acceptable' and 'unacceptable' behaviours for women and men and for mothers and fathers, thus reproducing prevailing patriarchal structures. The question of language as a means of exercising the power of differentiation and domination has been a frequent subject of feminist studies (Benor et al. 2002; Cameron 1990; Diamond and Quinby 1988; McNay 1992, 1994; Sawicki 1991; Smith 1990), particularly in feminist approaches to law.

I base much of my argument on what took place in open court, but I also draw upon documents and court hearings that are not available to the casual visitor, ${ }^{13}$ namely the reports on the "moral and socio-economic situation" of the child's mother prepared by the GNR, PSP or Social Services. I also analysed a sample of 1257 lawsuits of unofficial inquiry of paternity prosecuted in the court selected for study between 1967 and 2000. In 2000 and 2001 I interviewed 18 judges (5 women and 13 men) and 20 prosecuting counsels (2 women and 18 men), working in courts situated in different parts of the country, who volunteered to participate in the study in response to an invitation letter which advertised the research. In addition, I studied relevant jurisprudence published in Portuguese law reviews during the period 1967-2000, and investigated the evolution of judicial investigation of paternity proceedings through the analysis of court decisions available on the website of the Portuguese Justice Ministry, covering the period 1998-2007.

In the following discussion I present excerpts of text from these diverse sources which I consider particularly illustrative of the specific points being advanced. A feminist discourse analysis was used and themes were identified by reading transcriptions of interviews, jurisprudence and my notes from the observation of court hearings. I was interested to focus on the various ideological functions of the discourses and practices of judges and prosecuting counsels in the specific context of courtroom investigations of paternity, intending to explore how they reinforced gender inequalities, in particular by constructing a concept of paternity based on biological links between a man and a child, and an understanding of motherhood grounded on the assessment of moral profiles, directly connected to the evaluation of the mother's sexual behaviour.

In the judicial investigation of paternity, the present and past history of the mother's sexual life is of major relevance, insofar as it will condition the results of the lawsuit. The child's mother is prompted by an agent of the prosecuting counsel to answer certain questions about her sexual life, such as the number of sexual partners prior to her relationship with the person indicated as being the child's father, type of sexual intercourse engaged in with the alleged father, places and dates of those instances of sexual intercourse with the alleged father, reasons for maintaining the sexual relationship, use of birth control methods and the

\footnotetext{
13 After obtaining permission from the Portuguese Ministry of Justice, my access to documentation and to hearings that are closed to the public in general was authorised by the Chief Judge of the local court.
} 
alleged father's reaction to the news of the pregnancy. With these, the answer to two other questions is sought: whether, during the so-called "legal period for the minor's conception", ${ }^{14}$ his or her mother and the alleged father had sexual intercourse of "complete copulation"; 15 and whether, in the same legal period of conception, the mother had sexual intercourse solely with the alleged father. Basically, the mother is asked about her practice of heterosexual sexual intercourse involving penile-vaginal penetration, as well as about the number of sexual partners she had before and during the period of time Portuguese law considers susceptible of involving the conception of the child whose paternity is being investigated.

Despite its façade of neutrality and objectivity, law reinforces the prevailing order by expressing multiple ideologies (Jasanoff 2004). In the 1980s and 1990s, researchers from a range of disciplines asserted the importance of the 'social' in the construction of language, which undermined some significant aspects of legal rhetoric-namely, the idea frequently expressed by juridical science that the law is some sort of autopoetic entity which is self-legitimating and self-constructive. As Pierre Bourdieu notes, this rhetoric provides a fundamental basis for the legitimacy of judicial power:

The body of jurists has so little difficulty in convincing itself that the law is based upon itself... [and] the social cohesion of those who interpret the law tends to give the impression of a transcendental enforcement to historic forms of juridical reason, as well as to the belief in an organised vision of the social order they produce... (Bourdieu 1986, p. 5 [author's translation])

Observing courtroom hearings in paternity investigation cases allowed me to understand how the language used in the courtroom plays a crucial role in the production and exercise of power, which is particularly clear in the formulation of questions directed to mothers. Indeed, through judicial paternity hearings, the sexual and reproductive activity of the mother is no longer seen as an intimate and private experience, but becomes a matter of interest to the state, in the name of the defence of the child's interests, namely his or her right to know his or her genetic history. ${ }^{16}$ Yet the child's right to know implicates the right of others, i.e. in some instances the mother's conflicting right to privacy ${ }^{17}$ (Wallbank 2004). Facts that are in no way relevant to the case in question are brought up in the court room, namely those that

\footnotetext{
14 According to article 204 of the Minors Tutelary Organisation and articles 1795 and following of the Civil Code, the so-called "legal period of conception" corresponds to the first 120 days out of the 300 that preceded the minor's birth.

15 As Beleza (1993) states, Portuguese law and jurisprudence restricts the notion of "copulation" to the penetration of the vagina by the man's penis. "Complete" copulation is copulation accompanied by the release of sperm.

16 In Portugal, the individual's right to "genetic identity" was introduced into the Constitution in 1997, article 26 , no 3 .

17 Article 8 of the European Convention on Human Rights states that: "Everyone has the right to respect for his private and family life, his home and his correspondence".
} 
refer to the sexual life of the child's mother, ${ }^{18}$ although the judges I interviewed frequently repeated that the mother's sexual behaviour in the periods before and after the time of the child's conception was of no interest.

Let us look at the following example, in which the mother was a textile worker and the alleged father was a businessman who had spent 3 years in prison for homicide and who was also suspected of living off immoral earnings from the economic exploitation of prostitutes. The judge begins the interview with the mother by questioning her about her fidelity to the alleged father during the long period of time that he spent in prison. The implicit message is that it seems 'abnormal' for an adult woman to spend years without having a relationship.

Judge: The father of the minor was in prison for 3 years. And during this time, didn't you have any other men-friends?

The mother answers according to an ideal portrait of feminine behaviour, which displays domesticity and faithfulness.

Mother: No, Sir. I went to visit him every weekend and on public holidays, and I went straight home after the visit. I never left home, not even to go for a walk. It was just home, at work and made prison visits.

The judge goes on questioning her about her past relationships:

Judge: So, you never had other boyfriends?

Mother: Not since I met him.

The judge shows surprise and suspicion regarding this testimony of chastity and invites the mother to be more sincere, trying at the same time to assure her that her sexual history will not damage her intentions to see the paternity of her child legally recognised.

Judge: And before, did you have other boyfriends? I know the past is of no interest, and this will not go down on record, but it will make things clearer.... Mother: I had two boyfriends before him.

At this point of the inquiry, the judge moves to a position of paternalism, showing comprehension and sympathy for the mother's situation of 'falling into the temptation' of love and sex:

Judge: And did you have sexual relations with them?

\footnotetext{
${ }^{18}$ According to some feminist writers, in adversarial juridical systems, it is common for the defence to try to emphasise details of women's sexual lives (namely, their sexual history) in rape (Chambers and Millar 1987; Matoesian 1993) and sexual harassment cases, in order to try to prove that the woman in question is not 'worthy' of a favourable decision because she is, for example, considered 'promiscuous'. Indeed, the strategy of making public certain facets of the private life of people involved in legal proceedings would appear to be quite frequent when it comes to the administration of justice, including criminal justice. As Pat Carlen stresses: "Defendants are set up in a guarded dock and then, at a distance stretched beyond the boundaries of face to face communication, asked to describe or comment on intimate details of their lives; details which do not in themselves constitute infraction of any law but which are open to public investigation once a person has been accused of breaking the law" (Carlen 1976, p. 23).
} 
Mother: I did, with one of them. He was my boyfriend, and you know what it's like...

Judge: I see. That is of no interest. Do you realise you've wasted 6 years of your life with this individual [presumed father]?

Mother (resigned): I know, Sir. I completely lost my mind. I was in love. ${ }^{19}$

My direct observation of the everyday activities of courtrooms, in which face-to-face interactions between magistrates and citizens took place, also enabled me to detect some patterns of gender differentiation, which placed the mother in the realm of 'domesticity' and the alleged father in the realm of 'economics' (Boyd 1989; Brophy 1989; Eaton 1986; Silva and Smart 1999; Smart 1978, 1984; Smart and Sevenhuijsen 1989). An analysis of the questions directed to both the alleged father and the mother as to whether the alleged father contributed to the support of the child clearly revealed that the function of providing financial support was associated with the man. The following example is a dialogue between a prosecuting counsel and a man whom the mother alleged to be the biological father of her child. The prosecuting counsel wishes to determine if he intends to recognise paternity of the child, and at the same time, warns him about his paternal duty to support his child.

Prosecuting counsel: You never gave any type of support to the child... but it could be yours. How would you feel like if the child died of hunger and you found out later on that it was your child?!!!

The alleged father responds in a manner that expresses a biological notion of paternity-from his perspective, the acknowledgment of paternity will only be made if the genetic test proves the biological link.

Alleged father: I'll have the tests to find out if I am the father. If I am, I'll give something-not much, because I only earn 80 contos [400 euros] and I'm still paying back the bank loan on my car. ${ }^{20}$

The ideology of the breadwinning male is very clear here: while the mother is asked about her sexual life in order to indicate the identity of the father of her child, the putative father is asked about his willingness to provide financial support. It is interesting to note that although the putative father is encouraged to fulfil his role as financial supporter of the child, the fact is that there is strong evidence, drawing from my interviews with judges and prosecuting counsels working in different courts, that most legal fathers do not assume parental responsibilities and rights as carers or even as financial providers. The perceived importance of fatherhood for the legal system lies primarily in the guarantee of the child's right to personal identity, thus in the symbolic function of fatherhood as completing the ideal model of heterosexual, preferably married parents (Dewar 1998; Sheldon 2005), and only secondarily in the father's role as breadwinner. Little is known about the social and economic impacts of legal determinations of

\footnotetext{
19 Excerpt from field notes, December 2000.

${ }^{20}$ Excerpt from field notes, January 2001.
} 
paternity, although some studies carried out in the United States (Adams et al. 1992; Pirog-Good and Good 1995), as well as in some European countries (European Commission 1997), show that very few of these legal fathers live with their children or make any contact with them, or contribute to their children's financial support. Some authors also claim that the outcome of paternity investigation proceedings in relation to child support payments might be improved if there was a public policy of routinely monitoring biological fathers' fulfilment of their child support obligations (Garfinkel and Klawitter 1990).

\section{Locating Judicial Uses of Genetic Testing in Paternity Cases}

Nowadays, one of the outstanding features of the judicial investigation of paternity is the growing use of genetic profiling to assist the courts' role, which has been described as a complex collaboration, since "In their by no means friction-free encounter, neither science nor law completely retains or completely relinquishes its autonomy" (Jasanoff 2006, p. 239). Genetic fingerprinting can be used to prove or disprove a biological parental tie, with a very small margin for error. Nevertheless, some authors point out the problem that legal systems that use science as evidence in paternity suits do not always take into account the necessary balance between biological truth and social bonds (sociological and psychological truth) (AssierAndrieu and Commaille 1995; Eriksson and Saldeen 1993; European Commission 1997).

My study included an analysis of judicial practice regarding the use of genetic test results in investigations of paternity, in those cases in which paternity tests were ordered as an element of the evidence. The oldest of these cases began in 1974 and the latest in 2000, with a total of 85 cases involving 87 laboratory tests (in two of the cases blood samples from two alleged fathers were analysed). This aspect of paternity investigation proceedings is of interest not only because of its economic consequences (as the genetic tests are a rather expensive cost to the state), but mainly due to its individual, familial and social repercussions (Frank 1996; Sheldon 2001).

\section{Social Disadvantage in Access to Paternity Testing}

The Portuguese legal system does not collect or publish information that would enable a social, economic and demographic characterisation of the population involved in paternity investigations. The available evidence suggests, however, that most of the people involved in this type of lawsuit come from social groups deprived of cultural and economic resources. The majority of the population in my case study had blue collar occupations, with an almost complete absence of white collar professionals. Moreover, the jurisprudence of several courts dealing with these cases, published in legal magazines, frequently points out the impoverished conditions of the participants, especially the child's mother, in order to reinforce the state's protective role which, by identifying the father, tries to ensure the child's economic support. 
The 'social disadvantage' profile was also mentioned in the interviews, allowing the justification of distinct and often contradictory decisions concerning whether or not to perform DNA testing. The following excerpt illustrates the way that 'poverty' may be used to justify the request for DNA testing, suggesting that poverty may be accompanied by lack of information and naivety, casting the woman as an innocent victim of the male's sexual advances (Beleza 1993). Alternatively, the mother's poverty could be referred to in order to raise suspicions regarding her motives, implying that she was attempting to "catch a rich father". The situation of vulnerable handicapped women is also mentioned, stressing the need for the state's vigilant and protective role in these cases:

What sort of people come before me in cases of paternity investigation? They are usually people [referring to the child's mother] less cultivated, simple and humble. Normally, they are people who belong to a lower-middle social class, who are unaware of contraception or are deluded by an affair, and some men take advantage of such naivety... There are even cases of men who take advantage of handicapped women, and in those cases we must intervene. If not, what would become of the child? In other cases there are experienced women who seek to get out of a deprived livelihood, who don't have the best manners or great stability in affective or emotional terms and think that having a child may provide some stability to their lives and, therefore, they look for the ideal husband, preferably rich. $^{21}$

\section{Moralising Maternity}

The judicial magistrates' acceptance of the results given by forensic biology revealed a particular logic, characterised mainly by the fact that the moral and sexual behaviour of the child's mother still carried considerable weight in the determination of the legal paternity of the child, which in turn reinforced the predominant idea of institutional control of women's sexual and procreative behaviour. In cases in which genetic test results were presented as evidence, two different kinds of results emerged. On the one hand, there were cases in which the judge stated that his decision concerning the establishment of legal paternity was based on the scientific report. By contrast, in the majority of cases, even though a direct link was evident between the laboratory results and the judicial decision, the decision was ultimately based on the existence of the traditional evidence of the child's mother having sexual intercourse exclusively with the putative father during the so-called conception period.

There was a vast array of examples of this kind of decision, and I will only consider one here. In 1994, in an ordinary lawsuit of paternity in which the genetic tests showed paternity practically proven, the judge considered that the case had grounds, not simply on the basis of the scientific evidence, but because he implicitly believed that the positive genetic test result showed that the child's mother only had sexual intercourse with the alleged father during the legal period of conception:

$\overline{21}$ Interview with prosecuting counsel, 2001. 
The reason for filing a lawsuit of investigation of paternity is the genetic fact of procreation, which is based on the generating act of pregnancy and consolidates biological affiliation. The biological affiliation will have to be established on the evidence of the exclusiveness of sexual intercourse with the future father during the legal period of conception... And, as stated in the records pertaining to this sentence, the minor's mother, during his legal period of conception, had sexual intercourse with the defendant, which she did exclusively. ${ }^{22}$

In those cases in which the judge explicitly relied upon the results of the genetic tests, similar considerations were nonetheless evident, as seen, for example, in the following ruling on an unofficial investigation of paternity, concluded in 1994:

The minor's mother states that she has never had sexual intercourse with any other man... However, a paternity test was done in the Instituto de Medicina Legal [Forensics Institute] in Porto, from which could be concluded that the designated father was excluded as the minor's father. Thus there is not, in our view, viability for a lawsuit of investigation of paternity to be filed. ${ }^{23}$

The division between 'good' and 'bad' women is thus based on the notion of appropriate feminine behaviour, defined according to social expectations and culturally elaborated according to the codes of the dominant social groups, in this case the judges and prosecuting counsels. The following conversation with a judge illustrates the way in which cases that 'deserve' paternity testing are selected, based on the judgement of the mother's sexual behaviour:

Researcher: Suppose a situation in which the mother elects only one man as the possible biological father of the child. If there is testimonial evidence that the child's mother had several sexual partners during the legal period of conception, would you demand a DNA test?

Judge: Yes, unless it's a rather abnormal situation-if there are 5, 6, 7 or 8... I'm not going to test every one of them!...

Researcher: And what is the criteria [in order to decide if you demand a test or not]?

Judge: The criteria, let us say, is one of normality. If the mother says she had been with this one, and that one, and another, there you go, these are more or less normal relationships. Now, if things are like that, if it's a thing, let's say, in which the mother knows that there were 5 or 6 , but that she had been with many more and doesn't know who they are, in that situation, I drop the case. ${ }^{24}$

The use of scientific proof in the form of DNA profiling has been widely accepted in the courts. Such scientific proof appears to be associated with the discourses of truth, objectivity and infallibility, albeit there are uncertainties and limits attached to its uses (Jasanoff 2006). For the actors in the judicial system, genetic paternity tests

\footnotetext{
22 Records of lawsuits of judicial investigation of paternity, 1974-2000.

23 Records of lawsuits of judicial investigation of paternity, 1974-2000.

24 Interview with judge, 2000.
} 
in paternity investigations are seen as a tool which enables law to converge with the ideal of objectivity, neutrality and rigour that dominant discourses bestow upon science. The above analysis shows, however, that the use of science in paternity investigations follows normative criteria associated with patriarchal and familial visions of gendered social relations. Blood tests in investigations of paternity are ordered only in those instances in which the mother is thought to have displayed 'good' moral and sexual behaviour.

A recent court decision (2006) suggests that there has been little change in this regard since my ethnographic study ended in 2001. In this case, a man who was attributed with the paternity of a child appealed to the Portuguese Supreme Court of Justice, demanding a second paternity test on the basis that the child's mother had not maintained exclusive sexual relations with him. The lower court had established his paternity on the evidence of exclusive sexual relations and a paternity test with a 99. 99\% match (practically proven paternity). The Supreme Court of Justice denied a second test, grounding its decision on the 'certainty' of paternity established by the first test and on the absence of evidence that could threaten the reputation of the child's mother as an honest woman. ${ }^{25}$ The judges' rulings regarding the cases in which scientific evidence should be requested, and their appraisals of the mother's credibility, are again based on normative standards concerning her sexual behaviour.

At first sight, it may appear that these decisions are culture-specific, associated with the strong persistence of conventional behaviour patterns which in Portuguese society have relegated women to the domestic sphere. However, similar tendencies to monitor women's behaviour have been identified in an analysis of local practices of paternity establishment in Wisconsin, USA (Monson 1997). The author suggests that the practices of paternity establishment reproduce patriarchal gender relations by focusing on the unmarried mother's sexual activity and partners, whether birth control was used and whether pregnancy was intended, as a means to evaluate her overall truthfulness and “to make judgements about the woman's (not the man's) character” (Monson 1997, p. 288).

\section{Conclusion}

The Portuguese law which imposes on the state a duty to investigate the paternity of any child whose birth certificate does not mention the identity of the father, is based upon the principle of the public duty to defend the child's interests, and seeks to legally establish the type of affiliation bonds that are considered vital for the "moral integrity, better socialisation and economical support of the minor" (Pinto 1995, p. 243). However, in the context of the law in action, the defence of children's rights appears to be closely associated with the juridical evaluation of the mother's conformity or otherwise with the normative standards and dominant values of feminine sexual behaviour. The rhetoric of children's rights thus operates to legitimate the state's intervention to publicly monitor the private behaviours of

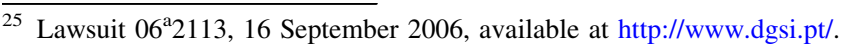


women who procreate outside conventional conjugal relationships. These women appear to constitute the preferred target for strategies of social control proceeding from the courts. As Emily Jackson states, "Women without men do not get any privacy, the prevailing wisdom is that they may be legitimately subjected to public, political and media scrutiny" (1997, pp. 53-54).

A judicial investigation of paternity results from a complex interrelationship between judicial and patriarchal power, which is also manifested in the institutional construction of negative images around single-parent families in which the father is absent. On the one hand, it is assumed that these are families with limited economic resources because they lack the father's contribution, which is seen as indispensable. On the other hand, these families are seen as potential sources of deviant behaviours, in the absence of the 'adequate' socialisation of their members, which occurs, precisely, due to the father's absence (Narayan and Bartkowiak 1999).

In the context of judicial paternity investigations, women who have children without legal fathers are subjected to familialist paternalistic strategies through which the legal system tries to impose the model of femininity and family life seen as being the most appropriate: the nuclear family and the woman who procreates within institutional marriage, who develops affective and sexual relationships considered 'stable'. Women are evaluated and classified in the light of moral standards that interrelate with the objectivity and certainty presented by forensic science through laboratory techniques of biological paternity testing.

The apparently neutral application of genetic tests in paternity investigation lawsuits in Portugal has important ideological and normalising effects, namely, in reproducing social gender distinctions already entrenched in Portuguese society. On the one hand, DNA testing offers a scientific means of reifying the biological basis of kin relationships that has, at least until relatively recent times, been assumed to provide the bedrock of kinship structures in western societies and that is clearly evident in Portuguese socio-legal and cultural understandings of parentage and kinship. On the other hand, by allowing the 'safe' ascertainment of paternity, genetic tests have given the courts further power of control over any female sexual and procreative behaviour that breaks away from the conventional standards of a woman's fidelity to a sole sexual partner, in the sense that a request for DNA testing might be denied to a mother who has admitted to having many sexual partners, even if she only points to a single man as being the probable father of her child.

A consideration of the present and future configurations of women's citizenship in Portugal points to the fact that it continues to be conditioned and limited in many situations. These limitations are aggravated whenever multidimensional vulnerabilities exist regarding class position, economic or labour dependence or sexual and procreative behaviours considered to be deviant. This state of affairs is reinforced by the political and regulatory culture still enforced today in Portugal. This culture is based on the central role assumed by the state in social regulation (in this case, by the imposition of paternity investigations), as well as on the authoritarian relationship between the state, the judicial system and certain institutional uses of science. The most disadvantaged citizens, such as working class mothers (the majority of the mothers who appear in paternity investigations) are those most likely to be affected, because they are particularly vulnerable to the harmful effects of 
'routine justice' which is a part of that culture. Yet routine justice also ensures the continuity of the system, not because it is satisfactory, but because passive citizenship prevails, grounded, on the one hand, on a weak internalisation of citizens' rights and a strong internalisation of the principle of non-application of laws or their selective application by the courts and, on the other hand, on a low motivation and feeble capacity to make claims (Santos et al. 1996). Routine court proceedings appear to be the most usual scenario in the context of a judicial practice which is triggered not by an actual mobilization of the judicial system by the citizens, but rather by a state imposition that, in a compulsory fashion, brings citizens into the courts. This is aggravated by the fact that women tend to have a more negative opinion of courts and to express more feelings of distance and incapacity to deal with them, which is consistent with the greater distance that women in general express with regard to public institutions (Santos et al. 1996), in virtue of the persistence of a patriarchal system which keeps them preferably within the private sphere and makes the state and the public sphere masculine.

The recent history of the practice of judicial paternity investigations has been marked by the growing use of DNA profiling to identify biological fathers. The laboratory tests concerning biological paternity have been perceived in the juridical field as tools for the introduction of further objectivity and exactness into affiliation law. Yet scientific evidence is a complex production, in the sense exposed by Jasanoff (1998), that draws on a wide range of social and cultural resources, such as the persuasiveness of inscriptions (in the case of paternity testing, 'DNA fingerprints'), the authority of professional codes and standards, and judges' and citizens' commonsense understandings of science (Jasanoff 2006). The symbolic subordination of law to science (Santos 1995) is clearly shown in the impact that scientific tests have on judicial decisions whenever a child's legal paternity is established. The results of the scientific tests are seen by the judges as mirrors of the sexual and moral behaviour of the child's mother, producing normative judgements legitimated by scientific ones. More than facilitating the judicial oversight of women's behaviour, the use of this scientific evidence seems to reinforce the monitoring of the sex life of the mothers of children without a legally recognised father, by the application of moralist criteria which exclude women reputed as sexually and affectively unstable, in order to select those cases deemed 'worthy' of DNA testing.

Acknowledgements This paper draws on research funded by the Portuguese Ministry of Science and Higher Education-Foundation for Science and Technology, and I acknowledge that support with gratitude. I also would like to thank Susana Silva (Faculty of Arts, University of Oporto) for her insightful comments on a first version of this text and Cátia Guimarães and Filomena Louro (Scientific Editing Programme, University of Minho) and Filipe Santos (Department of Sociology, University of Minho) for editorial advice.

\section{References}

Abbott, Pamela, and Claire Wallace, eds. 1991. Gender, power and sexuality. Basingstoke: Macmillan. Adams, Charles F., David Landsbergen, and Larry Cobler. 1992. Welfare reform and paternity establishment: A social experiment. Journal of Policy Analysis and Management 11: 665-687. 
Assier-Andrieu, Louis, and Jacques Commaille, eds. 1995. Politique des lois en europe: la affiliation comme modèle de comparaison. Paris: LGDJ.

Barton, Chris, and Gillian Douglas. 1995. Law and parenthood. London: Butterworths.

Beleza, Teresa. 1993. Mulheres, direito, crime ou a perplexidade de Cassandra. Dissertação de Doutoramento apresentada à Faculdade de Direito de Lisboa.

Benor, Sarah, Mary Rose, Devyani Sharma, and Julie Sweetland, eds. 2002. Gendered practices in language. Stanford: CSLI.

Boele-Woelki, Katharina. 2003. Perspectives for the unification and harmonisation of family law in Europe (European Family Law Series no 4). Antwerp: Intersentia Publishers.

Bourdieu, Pierre. 1986. La force du droit: élements pour une sociologie du champ juridique. Actes de la Recherche en Sciences Sociales 64: 3-19.

Boyd, Susan. 1989. From gender specificity to gender neutrality? Ideologies in Canadian child custody law. In Child custody and the politics of gender, ed. Carol Smart and Selma Sevenhuijisen, 126-157. London: Routledge.

Bridgeman, Joanna, and Susan Millns. 1995. Law and body politics: Regulating the female body. Aldershot: Dartmouth.

Brophy, Julia. 1989. Custody law, child care and inequality in Britain. In Child custody and the politics of gender, ed. Carol Smart and Selma Sevenhuijsen, 217-242. London: Routledge.

Cameron, Deborah, ed. 1990. The feminist critique of language: A reader. London: Routledge.

Carlen, Pat. 1976. Magistrates justice. London: Martin Robertson.

Carlen, Pat, and Anne Worral, eds. 1987. Gender, crime and justice. Milton Keynes: Open University Press.

Chambers, Gerry, and Ann Millar. 1987. Proving sexual assault: Prosecuting the offender or persecuting the victim? In Gender, crime and justice, ed. Pat Carlen and Anne Worrall, 58-80. Milton Keynes: Open University Press.

Conklin, William. 1998. The phenomenology of modern legal discourse: The juridical production and the disclosure of suffering. Brookfield: Ashgate.

Conley, John, and William O'Barr. 1998. Just words: Law, language and power. Chicago: University of Chicago Press.

Council of Europe. 1999. Legal problems relating to parentage. Strasbourg: Council of Europe.

Cretney, Stephen. 2003. Family law in the twentieth century: A history. Oxford: Oxford University Press.

Derksen, Linda. 2000. Towards a sociology of measurement: The meaning of measurement error in the case of DNA profiling. Social Studies of Science 30: 803-845.

Dewar, John. 1998. The normal chaos of family law. Modern Law Review 61: 467-482.

Diamond, Irene, and Lee Quinby, eds. 1988. Feminism and Foucault: Reflections on resistance. Boston: Northeastern University Press.

Diduck, Alison, and Felicity Kaganas. 1999. Family law, gender and the state: Text, cases and materials. Oxford: Hart Publishing.

Douglas, Gillian. 1991. Law, fertility and reproduction. London: Sweet and Maxwell.

Eaton, Mary. 1986. Justice for women? Family, court and social control. Philadelphia: Open University Press.

Eekelaar, John, and Petar Sarcevic, eds. 1993. Parenthood in modern society: Legal and social issues for the twenty-first century. Dordrecht: Martinus Nijhoff.

Epifânio, Rui, and António Farinha. 1992. Organização tutelar de menores (Decreto-Lei no 314/78, 27 de Outubro__contributo para uma visão interdisciplinar do direito de menores e da familia. Coimbra: Livraria Almedina.

Eriksson, Anders, and Ake Saldeen. 1993. Parenthood and science-establishing and contesting parentage. In Parenthood in modern society: Legal and social issues for the twenty-first century, ed. John Eekelaar and Petar Sarcevic, 75-92. Dordrecht: Martinus Nijhoff.

European Commission, Directorate-General XII, Science, Research and Development. 1997. Studies on the socio-economic impact of biotechnology: Genetic fingerprints, scientific truth and affiliation law. Luxembourg: Office for Official Publications of the European Communities.

Forder, Caroline. 1993. Constitutional principle and the establishment of the legal relationship between the child and the non-marital father: A study of Germany, the Netherlands and England. International Journal of Law and the Family 7: 40-107.

Frank, Rainer. 1996. Compulsory physical examinations for establishing parentage. International Journal of Law, Policy and the Family 10: 205-218.

Garfinkel, Irwin, and Marieka Klawitter. 1990. The effect of routine income withholding of child support collections. Journal of Policy Analysis and Management 9: 155-177. 
Gilbar, Roy. 2005. The status of family in law and bioethics: The genetic context. Aldershot: Ashgate. Gruen, Lori, and George E. Panichas, eds. 1997. Sex, morality and the law. London: Routledge.

Jackson, Emily. 1997. The child mother. In Family law and family policy in the new Europe, ed. Jacek Kurczewski and Mavis Maclean, 43-56. Aldershot: Dartmouth.

Jasanoff, Sheila. 1997. Science at the bar: Law, science and technology in America. Cambridge, MA: Harvard University Press.

Jasanoff, Sheila. 1998. The eye of everyman: Witnessing DNA in the Simpson trial. Social Studies of Science 28: 713-740.

Jasanoff, Sheila, ed. 2004. States of knowledge: The co-production of science and social order. Routledge: London; New York.

Jasanoff, Sheila. 2006. Just evidence: The limits of science in the legal process. Journal of Law, Medicine \& Ethics 34: 328-341.

Kilkely, Ursula. 2000. The child and the European Convention on Human Rights. International Journal of Children's Rights 8 (3): 299-301.

Lévi-Strauss, Claude. 1969. The elementary structures of kinship. London: Eyre and Spottiswoode.

MacKinnon, Catharine. 1987. Feminism unmodified: Discourses on life and law. Cambridge, MA: Harvard University Press.

Matoesian, Gregory M. 1993. Reproducing rape: Domination through talk in the courtroom. Oxford: Polity Press.

McGlynn, Clare M. 2002. Rights for children: The potential impact of the European Union Charter of Fundamental Rights. European Public Law 8: 387-400.

McGlynn, Clare M. 2006. Families and the European Union: Law, politics and pluralism. Cambridge: Cambridge University Press.

McNay, Lois. 1992. Foucault and feminism: Power, gender and the self. Cambridge: Polity Press.

McNay, Lois. 1994. Foucault: A critical introduction. Cambridge: Polity Press.

Meulders, Marie-Thérèse. 1993. Between nature and culture: The legal significance of parenthood in a changing world. In Parenthood in modern society: Legal and social issues for the twenty-first century, ed. John Eekelaar and Petar Sarcevic, ix-xii. Dordrecht: Martinus Nijhoff.

Monson, Renee A. 1997. State-ing sex and gender: Collecting information from mothers and fathers in paternity cases. Gender \& Society 11: 279-295.

Narayan, Uma, and Julia J. Bartkowiak, eds. 1999. Having and raising children: Unconventional families, hard choices and the social good. University Park, PA: Pennsylvania State University Press.

Phillips, Anne, ed. 1998. Feminism and politics. Oxford: Oxford University Press.

Pineau, Lois. 1997. Date rape: A feminist analysis. In Sex, morality, and the law, ed. Lori Gruen and George E. Panichas, 428-443. New York: Routledge.

Pinto, Fernando Brandão. 1995. Filiação natural. Porto: Ecla Editora.

Pinto, João Fernando. 2004. Estabelecimento da filiação. Prova pericial e evolução jurisprudencial. MaiaJuridica. Revista de Direito 2 (2): 97-125.

Pirog-Good, Maureen, and David Good. 1995. Child support enforcement for teenage fathers: Problems and prospects. Journal of Policy Analysis and Management 14: 25-42.

Portuguese Ministry of Justice. 1996-2004. Statistics of Justice, 1996-2004. http://www.gplp.mj.pt/ estjustica/. Accessed January 2007.

Richardson, Janice. 2005. Feminist legal theory and practice: Rethinking the relationship. Feminist Legal Studies 13: 275-293.

Rothstein, Mark A., Thomas H. Murray, Gregory E. Kaebnick, and Mary Anderlik Majumder, eds. 2005. Genetic ties and the family. Baltimore: Johns Hopkins University Press.

Santos, Boaventura de Sousa. 1995. Towards a new common sense: Law, science and politics in the paradigmatic transition. London: Sage.

Santos, Boaventura de Sousa, João Pedroso, and Maria Manuel Leitão Marques. 1996. Os tribunais nas sociedades contemporâneas. O caso português. Porto: Afrontamento.

Sawicki, Jana. 1991. Disciplining Foucault: Feminism, power and the body. London: Routledge.

Senaeve, Patrick. 1993. The reform of affliation law in France and the Benelux Countries. In Parenthood in modern society: Legal and social issues for the twenty-first century, ed. John Eekelaar and Petar Sarcevic, 93-111. Dordrecht: Martinus Nijhoff.

Sheldon, Sally. 2001. Unmarried fathers and parental responsibility: A case for reform? Feminist Legal Studies 9: 93-118.

Sheldon, Sally. 2005. Reproductive technologies and the legal determination of fatherhood. Feminist Legal Studies 13: 349-362. 
Silva, Elizabeth B., and Carol Smart. 1999. The new family? London: Sage.

Smart, Carol. 1978. Women, sexuality and social control. London: Routledge.

Smart, Carol. 1984. The ties that bind: Law, marriage and the reproduction of patriarchal relationships. London: Routledge.

Smart, Carol. 1987. There is of course a distinction dictated by nature: Law and the problem of paternity. In Reproductive technologies: Gender, motherhood and medicine, ed. Michelle Stanworth, 99-117. Cambridge: Polity Press.

Smart, Carol. 1995. Law, crime and sexuality: Essays in feminism. London: Sage.

Smart, Carol, and Bren Neale. 1999. Family fragments?. Cambridge: Polity Press.

Smart, Carol, and Selma Sevenhuijsen, eds. 1989. Child custody and the politics of gender. London: Routledge.

Smith, Dorothy E. 1990. Text, facts and femininity: Exploring the relations of ruling. London: Routledge. Spaas, Lieve, ed. 1998. Paternity and fatherhood: Myths and realities. London: Macmillan.

Strathern, Marilyn. 1992. Reproducing the future: Anthropology, kinship and the new reproductive technologies. London: Routledge.

Wallbank, Julie. 2004. The role of rights and utility in instituting a child's right to know her genetic history. Social \& Legal Studies 13: 245-264. 